\title{
Cross-cultural adaptation and reliability analysis of the Brazilian version of Pediatric Balance Scale (PBS)
}

\section{Adaptação cultural e análise da confiabilidade da versão brasileira da Escala de Equilíbrio Pediátrica (EEP)}

Lílian G. K. Ries', Stella M. Michaelsen', Patrícia S. A. Soares², Vanessa C. Monteiro², Kátia M. G. Allegretti²

\begin{abstract}
Background: The Pediatric Balance Scale (PBS) was developed from a modified version of the Berg Balance Scale aiming to obtain a balance scale more appropriate for the child population. Objectives: To adapt the PBS into Brazilian-Portuguese and to evaluate the intra and inter-rater reliability of the Brazilian-Portuguese version of PBS. Methods: To perform the cross-cultural adaptation of the American version of PBS four translators were involved, who have performed two translations and their respective back-translations. Then, a review by a multidisciplinary committee and a subsequent an assessment of the equivalence of meaning between the back-translations and the original English scale were performed by 3 and 30 healthcare professionals respectively. The intra-rater reliability of the final version of the Brazilian-Portuguese PBS was evaluated using a test-retest design with one-week interval. The Brazilian-Portuguese version of the PBS was tested twice on the same day by two different raters to test the inter-rater reliability. The inter-rater reliability, which was measured from a video of the volunteers performance, was evaluated by comparing the score given by five raters independently. Reliability was evaluated by Intraclass Correlation Coefficient (ICC). Fifteen volunteers (11 2.7 years) diagnosed with Cerebral Palsy (CP) classified at level I and II on the Gross Motor Function Classification System (GMFCS) were assessed. Results: The reliability of the PBS total score for both intra-rater (ICC=0.85) and inter-rater $(I C C=0.91)$ was excellent. The inter-rater reliability (measured from the video) for the total score was also classified as excellent (ICC=0.98). Conclusion: The results showed adequate reliability for the PBS for pediatric population with CP diagnostic classified at level I and II on the GMFCS.
\end{abstract}

Keywords: cerebral palsy; balance; pediatrics; assessment; reliability; physical therapy.

\section{Resumo}

Contextualização: A Pediatric Balance Scale (PBS) foi desenvolvida a partir de uma modificação da Escala de Equilíbrio de Berg (EEB), visando obter uma escala de equilíbrio mais apropriada para a população infantil. Objetivos: Adaptar para o português-Brasil e avaliar a confiabilidade intra-avaliador e interavaliadores/observadores da versão brasileira da PBS. Métodos: Para a adaptação cultural da versão americana da PBS, foram envolvidos quatro tradutores que realizaram duas traduções e respectivas retrotraduções, uma revisão por um comitê multidisciplinar e uma avaliação subsequente da equivalência de significado entre as retrotraduções e o original (respectivamente três e 30 profissionais da área de saúde). A confiabilidade intra-avaliador da escala final em Português - Escala de Equilíbrio Pediátrica (EEP) - foi avaliada comparando-se duas avaliações repetidas pelo mesmo avaliador com o intervalo de uma semana. A confiabilidade interavaliadores foi testada comparando-se as avaliações de dois avaliadores diferentes que realizaram o teste no mesmo dia. A confiabilidade interobservadores, a partir do vídeo do desempenho dos voluntários, foi avaliada por meio da comparação da pontuação dada independentemente por cinco observadores. A confiabilidade foi avaliada por meio do Coeficiente de Correlação Intraclasse (CCI). Foram avaliados 15 voluntários (11 $\pm 2,7$ anos) com diagnóstico de Paralisia Cerebral (PC), classificados nos níveis I e II do Sistema de Classificação da Função Motora Grossa (GMFCS). Resultados: A confiabilidade para o escore total da EEP foi excelente tanto para o teste intra-avaliador $(\mathrm{CCl}=0,85)$ como para o interavaliadores $(\mathrm{CCl}=0.91)$. A confiabilidade interobservadores (a partir do vídeo) para o escore total foi excelente $(\mathrm{CCl}=0,98)$. Conclusão: Os resultados mostraram confiabilidade adequada para a EEP para a população pediátrica com diagnóstico de PC classificada nos níveis I e II do GMFCS.

Palavras-chave: paralisia cerebral; equilíbrio; pediatria; avaliação; confiabilidade; fisioterapia.

\section{Received: 06/17/2011 - Revised: 12/13/2011 - Accepted: 01/15/2012}

${ }_{1}^{1}$ Postgraduate Program in Physical Therapy, Universidade do Estado de Santa Catarina (UDESC), Florianópolis, SC, Brazil

${ }^{2}$ Universidade Federal de São Paulo (UNIFESP), São Paulo, SP, Brazil

Correspondence to: Lílian Gerdi Kittel Ries, PPG Fisioterapia, CEFID/UDESC, Rua Pascoal Simone, 358, Bairro Coqueiros, Florianópolis, SC, Brasil, CEP 88080-350, e-mail: lílian.ries@udesc.br; liliangkr@yahoo.com.br 


\section{Introduction $: \therefore$.}

Cerebral Palsy (PC) is defined as a group of permanent disorders of the development of movement and posture, which are attributed to non-progressive disturbances that occurred in the developing fetal or infant brain causing activity limitation. The motor disorders of $\mathrm{CP}$ are often accompanied by disturbances of sensation, perception, cognition, communication and behavior, by epilepsy and by secondary musculoskeletal problems ${ }^{1}$. The limitations of a child with $\mathrm{CP}$ lead to the adoption of abnormal postures and movements that interfere with the global neuromuscular development and also with the postural control mechanism².

Although there are scales used in children with neuropsychomotor development disoders, which the mechanism of postural control is clinically evaluated during the performance of tasks that involves the control of body balance and mobili$\mathrm{ty}^{3-5}$, specific scales for evaluation of mobility and balance were predominantly developed for elderly population ${ }^{6-8}$.

One of the most used scales for the evaluation of balance is the Berg Balance Scale (BBS) ${ }^{7}$, which has been translated into Portuguese by Miyamoto et al. ${ }^{9}$. This scale was originally proposed to assess balance in the elderly population, however it has recently been used in both adults with neurological impairments ${ }^{10}$ and children populations $\mathrm{s}^{11-13}$.

Based on a pilot study with typically developed children, in which the BBS showed unsatisfactory test-retest reliability, Franjoine, Gunther and Taylor ${ }^{14}$ observed that most of the children tested had difficulty in maintaining the static postures. The authors of this piloty study proposed modifications in the 14 items of BBS in order to develop a balance scale more appropriate for children population. Therefore, the Pediatric Balance Scale (PBS) was developed as a modification of the BBS. In the pediatric version, the items were rearranged in a functional sequence, the time for maintaining the static postures was reduced, and the instructions and the suggested equipments were modified.

The original PBS was developed in New York, with American children, as a functional balance capacity measure of schoolaged children (5-15 yrs old) with mild to moderate motor impairment. This scale has high test-retest reliability and it allows variability in the score criterion on a single item. The scale contains 14 items evaluating functional activities that a child can perform at home, at school or in the community. This scale is relatively simple and of easy administration, with total time of administration of 15 minutes $^{14}$. In typically developed children, significant differences were observed on the performance of the PBS regarding age and gender, as well as the association between theirs scores with age, height, weight and body mass index ${ }^{15}$. In addition, the PBS was sensitive to changes in the functional balance in successive evaluations (with 4-month interval, during three years) of six children with mild to moderate $\mathrm{CP}^{16}$. The PBS was also linearly correlated with the Gross Motor Function Measure (GMFM) with $\mathrm{r}=0.87(\mathrm{p}=0.01)$ in a population of children with $\mathrm{CP}^{17}$. These studies used the dimensions $\mathrm{D}$ and $\mathrm{E}$ of the GMFM, which tests the child in standing position, walking, running and jumping, and they observed that the two tests complement each other.

Some authors have recommended the cross-cultural adaptation of scales and questionnaires existent in other cultures, supporting the idea that a good cultural and linguistic adaptation could facilitate the exchange of information among the scientific community ${ }^{18,19}$. Translations and adaptations of previously validated scales constitute a facilitator measure of the conduction and dissemination of health measurement ${ }^{18}$.

Reliable functional balance measures are important in the pediatric clinic as a manner of justifying an intervention or to evaluate the outcomes of interventions. To date, there are no studies carried out in the Brazilian community that used or validated the PBS. Therefore, this study aims to cross-culturally adapt the content of PBS and to evaluate the reliability of the Brazilian version for the use in the pediatric population with diagnosis of $\mathrm{CP}$.

\section{Methods: : :}

\section{Subjects}

Four translators and 33 health professionals worked on the cultural adaptation of the English version of $\mathrm{PBS}^{14}$. Fifteen volunteers from the physical therapy clinic of our institution were selected to participate on the reliability of the PBS. They had the diagnosis of CP and were classified at levels I and II of the Gross Motor Function Classification System (GMFCS) ${ }^{20}$. To be included in the study the child should be able to remain in the standing position, without upper limbs support. Children with attention deficit disorder, the ones who used orthoses on the lower limbs and those with deficit in the capacity of understanding simple orders were excluded from the study.

This cross-cultural adaptation study was approved by the Ethics in Research Committee of the Universidade Federal de São Paulo (UNIFESP), Hospital São Paulo, São Paulo, SP, Brazil $\left(n^{\circ} 1109 / 06\right)$ and the reliability study was approved by the Ethics in Research Committee of Universidade do Estado de Santa Catarina (UDESC), Florianópolis, SC, Brazil (nº 191/2008). Everyone involved and the legal guardians of the volunteers with CP signed the informed consent term after explanations and agreed in participating in the study. 


\section{Translation and cross-cultural adaptation}

The adaptation of the original English version of $\mathrm{PBS}^{14}$ was carried out according to the guidelines from Guillemin ${ }^{21}$ and Beaton et al. ${ }^{22}$, following the recommendations of the Scientific Advisory Committee of the Medical Outcomes Trust ${ }^{23}$. The translation into Portuguese was conducted by two independent Brazilian translators who were proficient in English and aware of the objectives of the study. The translation was performed independently and the translators were asked to be precise with the words, avoiding interpretations of expressions or sentences. This stage aimed at the detection of divergent errors and interpretations of ambiguous items on the part of each one of the translators, that developed a consensual version of the instrument in Portuguese.

This $1^{\text {st }}$ version was back-translated into English by two independent translators, of American origin, fluent in Portuguese, and who had not participated in the previous stage. The two translators were not aware of the original version of the instrument as well as the objectives of the study. Two English versions were obtained and were reviewed by a multidisciplinary committee composed of three professionals (one medical doctor and two physical therapists), to develop the final version of PBS. This stage aimed to compare the original and final versions, using techniques structured to solve discrepancies, change the format, rejecting inappropriate terms, and to verify the equivalence of the original and final versions at the end of the process. Therefore, after the consensus, it was obtained a second version in Portuguese. The final version in Portuguese was applied to a group of 30 musculoskeletal and neurological physical therapists who answered a questionnaire related to the level of understanding of the alternatives, verifying possible doubts with regards to the terms used in the evaluation of PBS.

As well as BBS, the PBS contain 14 items and, for each one, the score ranging from 0 to 4 is used. Several items require that the volunteer maintains the position for a specific time. Progressively, more points are deduced if the time or the distance required are not met, if the volunteer's performance requires supervision or if the volunteer touches an external support or receives assistance from the examiner. The maximum score of the scale is 56, the higher the score, the better the balance. The necessary material for evaluation is described in Appendix 1. The BBS and PBS have different sequences of application of the evaluated items (Table 1).

\section{Reliability}

Reliability was evaluated when the same examiner applied the scale in different days (intra-rater), when two different examiners applied the scale (inter-rater) and when different observers (inter observers) defined the score through the videos of the volunteers' performance (excluding the eventual variability of each one). Before applying the scale in children with $\mathrm{CP}$, the two examiners trained its application, evaluating four typically developed children.

Thus, $15 \mathrm{CP}$ participants were assessed at three timepoints. The first two moments occurred with the test being applied by two independent examiners (examiner 1 and examiner 2), constituting the evaluation 1 (EV1) and the evaluation 2 (EV2). These evaluations were carried out in the same day with an interval of one hour. The third moment occurred with the evaluation of one of the previous examiners (examiner 1), repeated in a interval of one week constituting the evaluation 3 (EV3). During EV2 videos recordings were made. Five

Table 1. Items of the Berg Balance Scale - Brazilian version and Pediatric Balance Scale.

\begin{tabular}{llrl}
\hline & Berg Balance Scale & & Pediatric Balance Scale \\
\hline 1 & Sitting to standing & 1 & Sitting to standing \\
\hline 2 & Standing unsupported & 3 & Standing to sitting \\
\hline 3 & Sitting unsupported & 4 & Standing unsupported \\
\hline 4 & Standing to sitting & 5 & Sitting unsupported \\
\hline 5 & Transfers & 6 & Standing with eyes closed \\
\hline 6 & Standing with eyes closed & 7 & Standing with feet together \\
\hline 7 & Standing with feet together & 8 & Standing with one foot in front \\
\hline 8 & Reaching forward with outstretched arm & 9 & Standing on one foot \\
\hline 9 & Retrieving object from floor & 10 & Turning 360 degrees \\
\hline 10 & Turning to look behind & 11 & Turning to look behind \\
\hline 11 & Turning 360 degrees & 12 & Retrieving object from floor \\
\hline 12 & Placing alternate foot on stool & 13 & Placing alternate foot on stool \\
\hline 13 & Standing with one foot in front & 14 & Reaching forward with outstretched arm \\
\hline 14 & Standing on one foot &
\end{tabular}


independent observers (O1-O5), without previous knowledge of the English version, received the translated PBS, the videos and the scoring sheet.

\section{Statistical analysis}

Participants characteristics were calculated through descriptive analysis. Intraclass Correlation Coefficients (ICC) and their 95\% confidence intervals for the evaluation of intra-rater (EV1 x EV3) and inter-rater (EV1 x EV2) was used to evaluate the reliability. The inter-observers reliability (O1-O5), for the score of volunteers' performance based on the videos, was also evaluated using the ICC and $95 \%$ CIs. The following classification was used for interpreting the ICC values: weak reliability, ICC $<0.40$; moderate reliability ICC $\leq 0.75$; and excellent reliability, ICC $>0.75^{24}$. Data were analyzed using SPSS 17.0 for Windows and for all procedures the significance level was set at $5 \%(\mathrm{p}<0.05)$, with two-tailed distribution.

\section{Results : :}

\section{Cross-cultural adaptation}

The $1^{\text {st }}$ version of PBS, in Portuguese, and the two English versions were referred to a multidisciplinary committee to be analyzed. Modifications regarding grammatical errors, which could change and delay the understanding of the items, were performed. After the committee review, alternatives have been reformulated, and some terms were substituted by other similar ones, such as "rest supported" for "remain supported", "stationary" for "static", "stands up" for "capable to be standing". At the end of this process, it was obtained the $2^{\text {nd }}$ version, which was applied to 30 physical therapists. For the process of cross-cultural adaptation, it was established a confidence interval of $15 \%$ for the understood and non-understood alternatives. None of the items reached the threshold of 15\% (Table 2). Therefore, it was not necessary to make modifications on the scale, and then, this was considered the final Portuguese version of PBS.

\section{Descriptive statistics}

Fifteen volunteers with $\mathrm{CP}$ diagnosis (age $=11.0 \pm 2.7 \mathrm{yrs}$, weight $=33.4 \pm 9.2 \mathrm{~kg}$ and height $=140.6 \pm 14.2 \mathrm{~cm}$ ) participated in the reliability evaluation. Ten volunteers were classified at level I of GMFCS ${ }^{20}$, six had spastic hemiparesis CP; three had spastic diparetic and one had ataxia. Five volunteers were classified at level II, two had spastic hemiparesis and three had spastic diparetic.

\section{Intra-rater and inter-rater reliability of the PBS}

All participants scored 4 in the tasks $1-6$ and 12 of PBS, and the agreement between examiners was equal to $100 \%$. In the task 7 of PBS, only one examiner scored 3 for one of the volunteers. Due to the variability absence for the tasks 1-7 and 12 , it was not possible to calculate the reliability values for them, however, as the agreement was $100 \%$, it was attributed an ICC of 1 . For the other tasks, the individual reliability of these items was calculated (Table 3). Reliability was excellent for items 9, 10, 13 and 14 and weak for item 8 (standing with one foot in front). The intra-rater agreement was equal to $100 \%$ for items 1-6 and 12, excellent for items 9, 13 and 14 and moderate for item 8 .

\section{Inter-observers reliability for the score based on videos}

With regards to the item turning to look behind, three of the five observers scored 4 for all children and, in the itemretrieving object from floor, one of the observers scored 4 for all children. So, due to the absence of variability, it was not possible to calculate the ICC in these items. The other individual items, as well as the total score, showed an excellent inter-observer reliability (Table 4).

Table 2. Evaluation of the items contained in the scale, according to the level of professionals understanding $(n=30)$.

\begin{tabular}{lccccc}
\hline \multirow{2}{*}{ Scale } & \multicolumn{3}{c}{ Number of professionals who do not understand (\%) } \\
\cline { 2 - 5 } & $\begin{array}{c}\text { Instructions } \\
\text { Special/General }\end{array}$ & Instructions & Equipment & Rated \\
\hline Personal Data & 0 & - & - & - \\
\hline Item description & $2(7 \%)$ & - & - & - \\
\hline General instructions 1 & $2(7 \%)$ & - & - & - \\
\hline General instructions 2 & $2(7 \%)$ & - & - & - \\
\hline Equipment & $2(7 \%)$ & - & - & - \\
\hline Item 1 & $1(3 \%)$ & $3(10 \%)$ & 0 & 0 \\
\hline Item 2 & 0 & $1(3 \%)$ & 0 & $2(7 \%)$ \\
\hline Item 3 & - & $4(13 \%)$ & $2(7 \%)$ & $1(3 \%)$ \\
\hline Item 4 & 0 & $2(7 \%)$ & $1(3 \%)$ & $1(3 \%)$ \\
\hline Item 5 & - & $1(3 \%)$ & 0 & $3(10 \%)$ \\
\hline Item 6 & - & 0 & 0 & 0 \\
\hline Item 7 & - & 0 & 0 & 0 \\
\hline Item 8 & - & $2(7 \%)$ & 0 & $2(7 \%)$ \\
\hline Item 9 & - & $1(3 \%)$ & $1(3 \%)$ & $1(3 \%)$ \\
\hline Item 10 & - & $1(3 \%)$ & 0 & 0 \\
\hline Item 11 & - & $2(7 \%)$ & 0 & $4(13 \%)$ \\
\hline Item 12 & - & $2(7 \%)$ & 0 & $2(7 \%)$ \\
\hline Item 13 & - & 0 & $1(3 \%)$ & $1(3 \%)$ \\
\hline Item 14 & $(13 \%)$ & $3(10 \%)$ & $4(13 \%)$ & 0 \\
\hline & & & & \\
\hline
\end{tabular}


Table 3. Mean, standard deviation (SD), intra-rater and inter-rater reliability of scores of pediatric balance scale (PBS).

\begin{tabular}{|c|c|c|c|c|}
\hline Intra-rater & Mean (SD) EV1 & Mean (SD) EV3 & ICC $(95 \% \mathrm{CI})$ & $p$ \\
\hline 1. Sitting to standing & $4.0(0.0)$ & $4.0(0.0)$ & $1.00^{*}$ & \\
\hline 2. Standing to sitting & $4.0(0.0)$ & $4.0(0.0)$ & $1.00^{*}$ & \\
\hline 3. Transfers & $4.0(0.0)$ & $4.0(0.0)$ & $1.00^{\star}$ & \\
\hline 4. Standing unsupported & $4.0(0.0)$ & $4.0(0.0)$ & $1.00^{*}$ & \\
\hline 5. Sitting unsupported & $4.0(0.0)$ & $4.0(0.0)$ & $1.00^{*}$ & \\
\hline 6. Standing with eyes closed & $4.0(0.0)$ & $4.0(0.0)$ & $1.00^{*}$ & \\
\hline 7. Standing with feet together & $4.0(0.0)$ & $3.9(0.3)$ & ** & \\
\hline 8. Standing with one foot in front & $3.3(0.8)$ & $3.6(0.5)$ & $0.73(0.20-0.91)$ & $p=0.001$ \\
\hline 9. Standing on one foot & $2.1(1.2)$ & $2.5(1.2)$ & $0.83(0.50-0.94)$ & $p=0.01$ \\
\hline 10. Turning 360 degrees & $3.8(0.6)$ & $3.9(0.5)$ & - & ns \\
\hline 11. Turning to look behind & $3.9(0.5)$ & $3.9(0.4)$ & - & ns \\
\hline 12. Retrieving object from floor & $4.0(0.0)$ & $4.0(0.0)$ & $1.00^{*}$ & \\
\hline 13. Placing alternate foot on stool & $3.8(0.4)$ & $3.8(0.4)$ & 1.00 & \\
\hline 14. Reaching forward & $3.5(0.6)$ & $3.4(0.8)$ & $0.97(0.91-0.99)$ & $p<0.001$ \\
\hline Total & $52.2(3.0)$ & $53.0(2.6)$ & $0.85(0.55-0.95)$ & $p=0.001$ \\
\hline Inter-rater & & AV2 & & \\
\hline 1. Sitting to standing & & $4.0(0.0)$ & $1.00^{\star}$ & \\
\hline 2. Standing to sitting & & $4.0(0.0)$ & $1.00^{\star}$ & \\
\hline 3. Transfers & & $4.0(0.0)$ & $1.00^{*}$ & \\
\hline 4. Standing unsupported & & $4.0(0.0)$ & $1.00^{*}$ & \\
\hline 5. Sitting unsupported & & $4.0(0.0)$ & $1.00^{*}$ & \\
\hline 6. Standing with eyes closed & & $4.0(0.0)$ & $1.00^{\star}$ & \\
\hline 7. Standing with feet together & & $3.9(0.3)$ & $1.00^{\star}$ & \\
\hline 8. Standing with one foot in front & & $3.6(0.7)$ & $0.66(0.01-0.89)$ & $p=0.03$ \\
\hline 9. Standing on one foot & & $2.2(1.3)$ & $0.88(0.65-0.96)$ & $p<0.001$ \\
\hline 10. Turning 360 degrees & & $3.9(0.3)$ & $0.81(0.43-0.94)$ & $p=0.002$ \\
\hline 11. Turning to look behind & & $3.9(0.3)$ & - & ns \\
\hline 12. Retrieving object from floor & & $4.0(0.0)$ & $1.00^{*}$ & \\
\hline 13. Placing alternate foot on stool & & $3.7(0.6)$ & $0.90(0.71-0.97)$ & $p<0.001$ \\
\hline 14. Reaching forward & & $3.1(0.8)$ & $0.97(0.90-0.99)$ & $p<0.001$ \\
\hline Total & & $52.3(3.7)$ & $0.91(0.73-0.97)$ & $p<0.001$ \\
\hline
\end{tabular}

ICC=Intraclass Correlation Coefficient; $95 \% \mathrm{Cl}=95 \%$ confidence interval; ${ }^{*} \mid \mathrm{CC}=1.00$ assigned to the items with absence of variability $(\mathrm{SD}=0.0)$ and agreement of $100 \%$ between the raters. ${ }^{* \star} \mid \mathrm{CC}$ not calculated due to the absence of variability in R1.

Table 4. Mean, standard deviation (SD) for the five observers (01-05) of partial and total scores of pediatric balance scale (PBS) from videos and inter-rater reliability.

\begin{tabular}{lcccccc}
\hline Inter-rater & Mean (SD) 01 & Mean (SD) 02 & Mean (SD) 03 & Mean (SD) 04 & Mean (SD) 05 & ICC (95\%CI) \\
\hline 1. Sitting to standing & $4.0(0.0)$ & $4.0(0.0)$ & $4.0(0.0)$ & $4.0(0.0)$ & $4.0(0.0)$ & $1.00^{*}$ \\
\hline 2. Standing to sitting & $4.0(0.0)$ & $4.0(0.0)$ & $4.0(0.0)$ & $4.0(0.0)$ & $4.0(0.0)$ & $1.00^{*}$ \\
\hline 3. Transfers & $3.9(0.3)$ & $4.0(0.0)$ & $4.0(0.0)$ & $3.9(0.3)$ & $4.0(0.0)$ & \\
\hline 4. Standing unsupported & $3.9(0.3)$ & $4.0(0.0)$ & $3.8(0.3)$ & $3.9(0.3)$ & $3.9(0.3)$ & \\
\hline 5. Sitting unsupported & $4.0(0.0)$ & $4.0(0.0)$ & $4.0(0.0)$ & $4.0(0.0)$ & $4.0(0.0)$ & $1.00^{*}$ \\
\hline 6. Standing with eyes closed & $3.9(0.3)$ & $3.9(0.3)$ & $3.7(0.5)$ & $3.9(0.3)$ & $3.9(0.3)$ & $0.90(0.79-0.96)$ \\
\hline 7. Standing with feet together & $4.0(0.0)$ & $4.0(0.0)$ & $3.9(0.4)$ & $4.0(0.0)$ & $4.0(0.0)$ & \\
\hline 8. Standing with one foot in front & $3.3(0.8)$ & $3.5(0.6)$ & $3.4(0.8)$ & $3.4(0.8)$ & $3.8(0.4)$ & $0.91(0.81-0.97)$ \\
\hline 9. Standing on one foot & $2.8(1.4)$ & $2.7(1.3)$ & $2.8(1.4)$ & $2.9(1.3)$ & $2.7(1.4)$ & $0.99(0.98-0.99)$ \\
\hline 10. Turning 360 degrees & $3.8(0.6)$ & $3.9(0.4)$ & $3.8(0.6)$ & $3.6(0.8)$ & $3.9(0.3)$ & $0.85(0.69-0.94)$ \\
\hline 11. Turning to look behind & $3.9(0.5)$ & $4.0(0.0)$ & $3.8(0.4)$ & $4.0(0.0)$ & $4.0(0.0)$ & \\
\hline 12. Retrieving object from floor & $4.0(0.0)$ & $3.9(0.3)$ & $3.9(0.3)$ & $3.9(0.4)$ & $3.9(0.3)$ & \\
\hline 13. Placing alternate foot on stool & $3.7(0.6)$ & $3.9(0.4)$ & $3.7(0.6)$ & $3.6(0.7)$ & $3.9(0.4)$ & $0.86(0.70-0.94)$ \\
\hline 14. Reaching forward & $3.4(0.9)$ & $3.1(1.0)$ & $3.2(0.8)$ & $3.2(0.6)$ & $3.4(0.8)$ & $0.86(0.70-0.94)$ \\
\hline Total & $52.7(3.7)$ & $52.9(3.1)$ & $52.1(4.2)$ & $52.3(2.9)$ & $53.6(2.5)$ & $0.98(0.96-0.99)$ \\
\hline
\end{tabular}

ICC=Intraclass Correlation coefficient; $95 \% \mathrm{Cl}=95 \%$ confidence interval; *ICC $=1.00$ assigned to the items with absence of variability (SD=0.0) and agreement of $100 \%$ between the raters. ${ }^{*} \mid \mathrm{CC}$ not calculated by the absence of variability in the score of one or more of the observers. 


\section{Discussion $: \because$.}

Due to the importance of detection of balance disorders, the PBS was developed for pediatric population ${ }^{14}$. For the correct balance evaluation, validated and cross-culturally adapted instrument to allow comparisons among different populations is needed. To date, this instrument was not available in Portuguese. As demosntrated on this study, the reliability of the cross-culturally adapted version into Portuguese is very similar to the original English version of PBS.

The translation and cross-cultural adaptation of instruments should follow a standardized procedure ${ }^{21,22}$. Based on the criteria defined by Scientific Advisory Committee of the Medical Outcomes Trust, the cross-cultural adaptation of an instrument involves the evaluation of conceptual and linguistic equivalences and the evaluation of psychometric properties ${ }^{18}$. In this study, both the equivalence of meanings from both cultures and the maintenance of the meaning that each task presented in the original language were performed. The small changes that were performed in agreement with the suggestions of the multidisciplinary committee resulted in a greater understanding of the instrument.

The $\mathrm{BBS}^{7}$ has been already translated and cross-culturally adapted into Portuguese and showed a intra-rater and interrater reliability in a sample of seniors between 65 and 82 years of 0.97 and 0.98 , respectively9. The BBS was used to evaluate balance of children with typical development ${ }^{11}$ and with $\mathrm{CP}^{11,13}$. The study of Gan et al. ${ }^{13}$ used the BBS, although the PBS is mentioned, these authors considered that more evidences are necessary to support its validity. However, other study observed that balance measures in people with Friedreich's Ataxia were not well documented, suggesting more studies to determine the most appropriate instrument, considering the possibility to use the PBS in this population ${ }^{25}$.

The participants of this study had difficulty to stand in one foot and to reach forwards. A third of the children were unable to sustain for 3 seconds in one foot. In order to to reach forwards, they needed supervision or reached less than $12.5 \mathrm{~cm}$.

The study that developed the PBS observed a good reliability when it was used in school-aged children with mild and moderate motor impairments ${ }^{14}$. The sample of 20 children included eight children with diagnosis of spastic diplegia and two with hemiplegia, and the ICC values were 0.99 for both intra-rater and inter-rater reliability. In the present study, with volunteers between 7 and 15 years old with a diagnosis of CP, classified at the levels I and II of GMFCS, both the intra-rater and the interrater reliability of PBS were also high.

The PBS was also used to evaluate and to describe the functional balance of older typically developed children, newer typically developed children, children with ataxic $\mathrm{CP}$ and children with spastic $\mathrm{CP}^{26}$. In eight children with $\mathrm{CP}$ ( four spastic and four ataxic) of this study, aged between 10 and 14 years and levels of GMFCS between I and III, the mean score of PBS was 47.2 \pm 9.5 for the spastic and $48.5 \pm 6.24$ for the ataxic, lower than the ones of the present study. In the present study, volunteers had a total score that ranged between 46 and 56 points in the PBS, and the volunteers with spastic $\mathrm{CP}$ had a score of 52.1 \pm 3.1 , and the only volunteer with ataxic $\mathrm{CP}$ had the score of 53 points. The lowest score of the mentioned study ${ }^{26}$ is attributed to the greater impairments of the evaluated children, one spastic and two ataxic were classified at level III of GMFCS.

It was verified in the present study that although both intra-rater and inter-rater reliabilities have been high, the intra-rater reliability slightly lower than the inter-rater reliability. Considering that, for the intra-rater reliability (EV1 $x$ EV3), the evaluation was performed on different days and, for the inter-rater (EV1 x EV2), on the same day, the presence of variability in the behavior of the evaluated children on different days should be considered. This finding is reinforced when the variability due to the child's performance is eliminated in the reliability based on videos. When different observers scored the children's performance, the reliability of scale shows an ICC higher than the ones of intra and inter-rater reliability.

When the reliability of individual items was evaluated, it was observed that the task of standing with one foot in front had a lower, but still appropriate intra and inter-rater reliability. Still, in the task turning to look behind although the means were similar (3.9 points for the three evaluations and ranging between 3.8 and 4.0 points for observers 1 to 5), the ICC was not significant in none of the evaluated reliability conditions. It is possible that the observers have been influenced by the interpretation of the BBS, in which the score is given predominantly considering the weight transfer between the lower limbs and not the trunk rotation, such as in the PBS. It is important that the examiners, who have knowledge of the BBS, when using the PBS, be aware of such difference. In the original English version of PBS, the testretest reliability of this item achieved Kappa coefficient of 0.93 .

It was observed that for the studied sample, the total scores for balance were high and that, in several tasks all participants reached the maximum score of 4 points. As reported for the $\mathrm{BBS}^{27}$, the PBS presented a ceiling effect on 7 items. For futures studies, a simplified version of PBS should be considered in the evaluation of children with CP classified at levels I and II of GMFCS.

Reliable functional balance measures are important in the pediatric clinic for measuring the effects of interventions. The results showed appropriate reliability for PBS in children with diagnosis of CP classified at levels I and II of GMFCS. Thus, the translation into Portuguese of PBS, as well as the demonstration of its intra-rater reliability when different examiners apply the scale or observe the performance based on videos, should contribute as a facilitator alternative of the balance evaluation of the Brazilian pediatric population with diagnosis of $\mathrm{CP}$. 


\section{References : : :}

1. Rosenbaum P, Paneth N, Leviton A, Goldstein M, Bax M, Damiano D, et al. A report: the definition and classification of cerebral palsy April 2006. Dev Med Child Neurol Suppl. 2007;109:8-14.

2. Ries LGK, Bérzin F. Ativação assimétrica dos músculos temporal e masseter em crianças com paralisia cerebral. Fisioter Mov. 2009;22(1):45-52.

3. Russell DJ, Rosenbaum PL, Lane M, Gowland C, Goldsmith CH, Boyce WF, et al. Training users in the Gross Motor Function Measure: methodological and practical issues. Phys Ther. 1994;74(7):630-6.

4. Boyce WF, Gowland C, Rosenbaum PL, Lane M, Plews N, Goldsmith CH, et al. The Gross Motor Performance Measure: validity and responsiveness of a measure of quality of movement. Phys Ther. 1995;75(7):603-13.

5. Folios MR, Fewell RR. peabody developmental motor scales and activity cards. Chicago, III: Riverside Publishing Company; 1983.

6. Podsiadlo D, Richardson S. The timed "Up \& Go": a test of basic functional mobility for frail elderly persons. J Am Geriatr Soc. 1991;39(2):142-8.

7. Berg KO, Wood-Dauphinee SL, Williams JI, Maki B. Measuring balance in the elderly: validation of an instrument. Can J Public Health. 1992;83 Suppl 2:S7-11.

8. Shumway-Cook A, Woollacott MH. Motor control: theory and practical applications. Baltimore, MD: Williams \& Wilkins; 1995

9. Miyamoto ST, Lombardi Junior I, Berg KO, Ramos LR, Natour J. Brazilian version of the Berg balance scale. Braz J Med Biol Res. 2004;37(9):1411-21.

10. Wee JY, Wong H, Palepu A. Validation of the Berg Balance Scale as a predictor of length of stay and discharge destination in stroke rehabilitation. Arch Phys Med Rehabil. 2003;84(5):731-5.

11. Kembhavi G, Darrah J, Magill-Evans J, Loomis J. Using the Berg Balance Scale to distinguish balance abilities in children with cerebral palsy. Pediatr Phys Ther. 2002;14(2):92-9

12. Freivogel S, Mehrholz J, Husak-Sotomayor T, Schmalohr D. Gait training with the newly developed 'LokoHelp'-system is feasible for non-ambulatory patients after stroke, spinal cord and brain injury. A feasibility study. Brain Inj. 2008;22(7-8):625-32.

13. Gan SM, Tung LC, Tang YH, Wang CH. Psychometric properties of functional balance assessment in children with cerebral palsy. Neurorehabil Neural Repair. 2008;22(6):745-53.
14. Franjoine MR, Gunther JS, Taylor MJ. Pediatric Balance Scale: a modified version of the Berg Balance Scale for the school-age child with mild to moderate motor impairment. Pediatr Phys Ther. 2003;15(2):114-28.

15. Franjoine MR, Darr N, Held SL, Kott K, Young BL. The performance of children developing typically on the pediatric balance scale. Pediatr Phys Ther 2010;22(4):350-9.

16. Franjoine M. The performance of six school-age children with cerebral palsy on the Pediatric Balance Scale (PBS): a three year study of changes in functional balance. Pediatr Phys Ther. 2004;16(1):50.

17. Vrettos S, Dimoulas E, Skouteli HN. The relationship between functional balance and functional gross motor skills in children with cerebral palsy. Brain Dev. 2004;26:S38-9.

18. Ferreira PL, Marques FB. Avaliação psicométrica e adaptação cultural e lingüística de instrumentos de medição em saúde: princípios metodológicos gerais. Coimbra: Centro de Estudos e Investigação em Saúde; 1998.

19. De Barros EN, Alexandre NM. Cross-cultural adaptation of the Nordic musculoskeletal questionnaire Int Nurs Rev. 2003;50(2):101-8.

20. Palisano R, Rosenbaum P, Walter S, Russel D, Wood E, Gallupi B. Development and reliability of a system to classify gross motor function in children with cerebral palsy. Dev Med Child Neurol. 1997;39(4):214-23.

21. Guillemin F. Cross-cultural adaptation and validation of health measures. Scand J Rheumatol. 1995;24(2):61-3.

22. Beaton DE, Bombardier C, Guillemin F, Ferraz MB. Guidelines for the process of cross-cultural adaptation of self-report measures. Spine (Phila Pa 1976). 2000;25(24):3186-91.

23. Lohr KN. Assessing health status and quality-of-life instruments: attributes and review criteria. Qual Life Res. 2002;11(3):193-205.

24. Fleiss JL. Statistical methods for rates and proportions. $2^{\text {nd }}$ ed. New York: John Wiley \& Sons; 1999.

25. Maring JR, Croarkin E. Presentation and progression of friedreich ataxia and implications for physical therapist examination. Phys Ther. 2007:87(12):1687-96.

26. Reilly DS, Woollacott MH, van Donkelaar P, Saavedra S. The interaction between executive attention and postural control in dual-task conditions: children with cerebral palsy. Arch Phys Med Rehabil. 2008:89(5):834-42.

27. Salbach NM, Mayo NE, Higgins J, Ahmed S, Finch LE, Richards CL. Responsiveness and predictability of gait speed and other disability measures in acute stroke. Arch Phys Med Rehabil. 2001;82(9):1204-12. 
Appendix 1. Brazilian-Portuguese version of the Pediatric Balance Scale.

\begin{tabular}{l} 
Nome: \\
Data: \\
Local: \\
Examinador: \\
\hline Descrição do Item \\
\hline 1. Posição sentada para posição em pé \\
\hline 2. Posição em pé para posição sentada \\
\hline 3. Transferências
\end{tabular}

\section{Instruções Gerais}

1. Demonstre cada tarefa e forneça instruções conforme descrito. A criança poderá receber uma demonstração prática em cada item. Se a criança não conseguir completar a tarefa baseada em sua habilidade para entender as orientações, poderá ser realizada uma segunda demonstração prática. Orientações visuais e verbais poderão ser esclarecidas/fornecidas por meio do uso de dicas físicas.

2. Cada item deve ser pontuado utilizando-se a escala de 0 a 4 . São permitidas várias tentativas em todos os itens. 0 desempenho da criança deverá ser pontuado baseando-se no menor critério, que descreve 0 melhor desempenho da criança. Se, na primeira tentativa, a criança receber a pontuação máxima de 4, não será necessário administrar tentativas adicionais. Vários itens exigem que a criança mantenha uma determinada posição durante um tempo específico. Progressivamente, mais pontos são descontados se o tempo ou distância não forem alcançados; se 0 desempenho do indivíduo necessita de supervisão ou se o indivíduo toca um apoio externo ou recebe ajuda do examinador. Os indivíduos devem entender que eles precisam manter o equilíbrio enquanto tentam realizar as tarefas. A escolha sobre qual perna ficar em pé ou qual distância alcançar é decidida pelo indivíduo. Um julgamento pobre irá influenciar de forma negativa o desempenho e a pontuação. Além dos itens de pontuação 4, 5 , 6, 7, 8, 9, 10 e 13, 0 examinador poderá escolher registrar o tempo exato em segundos.

\section{Equipamento}

A Escala de Equilíbrio Pediátrica foi desenvolvida para exigir utilização mínima de equipamento especializado. A seguir, há uma lista completa de itens necessários para administração desta ferramenta:

- Banco de altura ajustável

- Cadeira com suporte no encosto e descanso para os braços

- Cronômetro ou relógio de mão
- Fita adesiva de 2,5 centímetros de largura

- Um apoio para os pés de 15 centímetros de altura

- Apagador de quadro negro

- Régua ou fita métrica

- Um pequeno nível (instrumento utilizado para verificar se um plano está horizontal)

Os itens seguintes são opcionais e poderão ser úteis durante a administração do teste:

- 2 moldes dos pés tamanho infantil

- Tapa-olhos (venda)

- Um objeto bem colorido medindo pelo menos 5 centímetros

- Cartões coloridos

- 5 centímetros de fita (duplo) velcro

- 2 fitas de $30 \mathrm{~cm}$ de velcro duplo

\section{Posição sentada para posição em pé}

* Instrução especial: Itens $n^{0} .1$ e $n^{0} .2$ podem ser testados simultaneamente se, na determinação do examinador, puder facilitar 0 melhor desempenho da criança.

\section{INSTRUCOÕES: Pede-se à criança para "Manter os braços para}

cima e ficar em pé". A criança poderá selecionar a posição dos braços. EQUIPAMENTO: Um banco de altura apropriada para permitir que os pés da criança permaneçam apoiados no chão com os quadris e joelhos mantidos a 90 graus de flexão.

\section{Melhor das três tentativas}

( ) 4 capaz de levantar-se sem utilizar as mãos e estabilizar-se de forma independente

( ) 3 capaz de levantar-se de forma independente utilizando as mãos

( ) 2 capaz de levantar-se utilizando as mãos após várias tentativas

( ) 1 necessita de ajuda mínima para levantar-se ou estabilizar-se

( ) 0 necessita de ajuda moderada ou máxima para levantar-se

\section{Posição em pé para posição sentada}

* Instrução especial: Itens no. 1 e $n^{0} .2$ podem ser testados simultaneamente se, na determinação do examinador, puder facilitar 0 melhor desempenho da criança.

\section{INSTRUCCÕES: Pede-se à criança para sentar-se devagar, sem utilizar as mãos. A criança poderá selecionar a posição dos braços.}

EQUIPAMENTO: Um banco de altura apropriada para permitir que os pés da criança permaneçam apoiados no chão com os quadris e joelhos mantidos a 90 graus de flexão.

\section{Melhor das três tentativas}

( ) 4 senta-se com segurança com utilização mínima das mãos

( ) 3 controla a descida utilizando as mãos

( ) 2 utiliza a parte de trás das pernas contra a cadeira para controlar a descida

( ) 1 senta-se de forma independente, mas tem descida sem controle

( ) 0 necessita de ajuda para sentar-se 


\section{Transferências}

INSTRUCÕES: Arrume as cadeiras perpendicularmente (90 graus) para uma transferência em pivô. Peça à criança para transferir-se de uma cadeira com apoio de braço para uma cadeira sem apoio de braço.

EQUIPAMENTO: Duas cadeiras ou uma cadeira e um banco de altura ajustável. Uma superfície do assento deve ter braços. Uma cadeira/banco deve ser de tamanho adulto padrão e a outra deve ter altura apropriada para permitir que a criança sente-se confortavelmente com os pés apoiados no chão e a noventa graus de flexão de quadril e joelho.

Melhor das três tentativas

( ) 4 capaz de transferir-se com segurança e uso mínimo das mãos

( ) 3 capaz de transferir-se com segurança com o uso das mãos

( ) 2 capaz de transferir-se seguindo orientações verbais e/ou supervisão (observação)

( ) 1 necessita de uma pessoa para ajudar

( ) 0 necessita de duas pessoas para ajudar ou supervisionar (monitoramento próximo) para sentir-se seguro

\section{Em pé sem apoio}

INSTRUCCÕES: Pede-se à criança que fique em pé por $\mathbf{3 0}$ segundos sem se apoiar ou mover seus pés. Uma fita adesiva ou moldes dos pés poderão ser colocados no chão para ajudar a criança a manter a posição estática dos pés. A criança poderá se envolver em uma conversa não estressante para manter 0 tempo de atenção por 30 segundos. Reações de troca de peso e equilíbrio nos pés são aceitáveis; o movimento do pé no espaço (fora da superfície de suporte) indica final do tempo do teste.

EQUIPAMENTO: Um cronômetro ou relógio de mão. Uma fita adesiva de $30 \mathrm{~cm}$ de comprimento ou dois moldes dos pés colocados separados equivalente à distância da largura dos ombros.

( ) 4 capaz de permanecer em pé por 30 segundos

( ) 3 capaz de permanecer em pé por 30 segundos sob supervisão (observação)

( ) 2 capaz de permanecer em pé por 15 segundos sem apoio

( ) 1 necessita de várias tentativas para permanecer em pé por 10 segundos sem apoio

( ) 0 incapaz de permanecer em pé por 10 segundos sem ajuda Tempo em segundos

Instruções especiais: Se a criança puder permanecer em pé por 30 segundos sem apoio, marque pontuação máxima para sentar-se sem apoio no item $n^{0}$. 5. Continue com 0 item $n^{0} .6$.

\section{Sentando sem apoio nas costas e com os pés apoiados no chão}

INSTRUÇÕES: Por favor, sente-se com os braços cruzados sobre seu peito por $\mathbf{3 0}$ segundos. A criança poderá se envolver em uma conversa não estressante para manter o tempo de atenção por 30 segundos. 0 tempo deverá ser interrompido se reações de proteção no tronco ou extremidades superiores forem observadas.
EQUIPAMENTO: Um cronômetro ou relógio de mão. Um banco de altura apropriada para permitir que os pés fiquem apoiados no chão com os quadris e joelhos mantidos a noventa graus de flexão.

( ) 4 capaz de sentar-se de forma segura por 30 segundos

( ) 3 capaz de sentar-se por 30 segundos sob supervisão (observação) ou pode necessitar de uso definitivo das extremidades superiores para manter-se na posição sentada

( ) 2 capaz de sentar-se por 15 segundos

( ) 1 capaz de sentar-se por 10 segundos

( ) 0 incapaz de sentar-se sem apoio por 10 segundos Tempo em segundos

\section{Em pé sem apoio com os olhos fechados}

INSTRUCÕ̃ES: Pede-se à criança que fique em pé parada com os pés separados equivalente à largura dos ombros e feche os olhos por 10 segundos. Orientação: "Quando eu disser feche os olhos, eu quero que você fique parada, feche os olhos e mantenha-os fechados até eu dizer para abri-los". Se necessário, pode-se usar um tapa-olhos. Reações de troca de peso e equilíbrio nos pés são aceitáveis; movimento do pé no espaço (fora da superfície de suporte) indica o final do tempo do teste. Uma fita adesiva ou moldes dos pés poderão ser colocados no chão para ajudar a criança a manter a posição estática dos pés.

EQUIPAMENTO: Um cronômetro ou relógio de mão. Uma fita adesiva de 30 centímetros ou dois moldes dos pés colocados separados equivalente à distância da largura dos ombros, um tapa olhos.

Melhor das três tentativas

( ) 4 capaz de permanecer em pé por 10 segundos de forma segura

( ) 3 capaz de permanecer em pé por 10 segundos com supervisão

( ) 2 capaz de permanecer em pé por 3 segundos

( ) 1 incapaz de permanecer com os olhos fechados por 3 segundos, mas mantém-se firme

( ) 0 necessita de ajuda para evitar queda Tempo em segundos

\section{Em pé sem apoio com os pés juntos}

INSTRUÇÕES: Pede-se que a criança coloque seus pés juntos e fique em pé parada sem segurar-se. A criança poderá se envolver em uma conversa não estressante para manter o tempo de atenção por 30 segundos. Reações de troca de peso e equilíbrio nos pés são aceitáveis; movimento do pé no espaço (fora da superfície de suporte) indica o final do tempo do teste. Uma fita adesiva ou moldes dos pés poderão ser colocados no chão para ajudar a criança a manter a posição estática dos pés.

EQUIPAMENTO: Um cronômetro ou relógio de mão, uma fita adesiva de 30 centímetros ou dois moldes dos pés colocados juntos.

\section{Melhor das três tentativas}

( ) 4 capaz de posicionar os pés juntos de forma independente e permanecer em pé por 30 segundos de forma segura

( ) 3 capaz de posicionar os pés juntos de forma independente e permanecer em pé por 30 segundos com supervisão (observação) 
( ) 2 capaz de posicionar os pés juntos de forma independente, mas não pode sustentar por 30 segundos

( ) 1 necessita de ajuda para posicionar-se, mas é capaz de permanecer em pé por 30 segundos com os pés juntos

( ) 0 necessita de ajuda para posicionar-se e/ou é incapaz de permanecer nessa posição por 30 segundos

Tempo em segundos

\section{Em pé sem apoio com um pé à frente}

INSTRUÇÕES: Pede-se à criança que fique em pé, com um pé à frente do outro, com o calcanhar tocando os dedos do pé de trás Se a criança não conseguir colocar os pés um à frente do outro (diretamente na frente), pede-se que dê um passo à frente o suficiente para permitir que o calcanhar de um pé seja colocado à frente dos dedos do pé fixo. Uma fita adesiva e/ou moldes dos pés poderão ser colocados no chão para ajudar a criança a manter a posição estática dos pés. Além de uma demonstração visual, poderá ser dada uma dica física simples (assistência com colocação). A criança poderá se envolver em uma conversa não estressante para manter o tempo de atenção por 30 segundos. Reações de troca de peso e/ou equilíbrio nos pés são aceitáveis. 0 tempo do teste poderá ser interrompido se qualquer um dos pés se mover no espaço (deixar a superfície de suporte) e/ou as extremidades superiores forem utilizadas.

EQUIPAMENTO: Um cronômetro ou relógio de mão, uma fita adesiva de 30 centímetros ou dois moldes dos pés colocadas na direção calcanhar aos dedos do pé.

\section{Melhor das três tentativas}

( ) 4 capaz de colocar um pé à frente do outro de forma independente e sustentar por 30 segundos

( ) 3 capaz de colocar o pé adiante do outro de forma independente e sustentar por 30 segundos

Obs.: 0 comprimento do passo deve exceder o comprimento do pé fixo, e a largura da posição em pé deve aproximar-se da largura do passo normal da criança.

( ) 2 capaz de dar um pequeno passo de forma independente e sustentar por 30 segundos ou necessita de ajuda para colocar um pé à frente, mas pode ficar em pé por 30 segundos

( ) 1 necessita de ajuda para dar o passo, mas permanece por 15 segundos

( ) 0 perde 0 equilíbrio ao tentar dar o passo ou ficar em pé Tempo em segundos

\section{Em pé sobre uma perna}

INSTRUCÕES: Pede-se que a criança fique em pé sobre uma perna o máximo que puder sem se segurar. Se necessário, a criança poderá ser instruída a manter seus braços ao longo do corpo ou com as mãos na cintura. Uma fita adesiva e/ou moldes dos pés poderão ser colocados no chão para ajudar a criança a manter a posição estática dos pés. Reações de troca de peso e/ou equilíbrio nos pés são aceitáveis. 0 tempo do teste poderá ser interrompido se o pé que está sustentando o peso mover-se no espaço (deixar a superfície de suporte); se o membro superior tocar a perna oposta ou se a superfície de apoio e/ou extremidades superiores forem utilizadas para apoio.
EQUIPAMENTO: Um cronômetro ou relógio de mão, uma fita adesiva de 30 centímetros ou dois moldes dos pés colocadas na direção calcanhar para os dedos do pé.

\section{Melhor das três tentativas}

( ) 4 capaz de levantar a perna de forma independente e sustentar por 10 segundos

( ) 3 capaz de levantar a perna de forma independente e sustentar de 5 a 9 segundos

( ) 2 capaz de levantar a perna de forma independente e sustentar de 3 a 4 segundos

( ) 1 tenta levantar a perna; é incapaz de sustentar por 3 segundos, mas permanece em pé

( ) 0 incapaz de tentar ou necessita de ajuda para evitar queda

\section{Girar 360 graus}

INSTRUCÕES: Pede-se para a criança girar completamente em torno de si mesma em uma volta completa, PARE, e então gire completamente em torno de si mesma na outra direção.

\section{EQUIPAMENTO: Um cronômetro ou relógio de mão.}

( ) 4 capaz de girar 360 graus de forma segura em 4 segundos ou menos cada volta (total menor que 8 segundos)

( ) 3 capaz de girar 360 graus de forma segura somente em uma direção em 4 segundos ou menos; para completar a volta na outra direção requer mais que 4 segundos

( ) 2 capaz de girar 360 graus de forma segura, mas lentamente

( ) 1 necessita de supervisão próxima (observação) ou dicas verbais constantes

( ) 0 necessita de ajuda enquanto gira Tempo em segundos

11. Virar e olhar para trás por cima do ombro esquerdo e direito enquanto permanece em pé

\section{INSTRUCÕES: Pede-se à criança que fique em pé com seus pés parados, fixos em um lugar. "Siga este objeto conforme eu for movimentando-0. Mantenha o olhar enquanto ele se move, mas não movimente os pés".}

EQUIPAMENTO: Um objeto bem colorido medindo pelo menos 5 centímetros ou cartões coloridos, uma fita adesiva de 30 centímetros de comprimento ou dois moldes dos pés colocados separados equivalente à distância dos ombros.

( ) 4 olha para trás por cima de cada ombro; a troca de peso inclui rotação do tronco

( ) 3 olha para trás e sobre o ombro com rotação do tronco; a troca de peso na direção oposta ao ombro; não há rotação do tronco

( ) 2 vira a cabeça para olhar no nível do ombro; não há rotação do tronco

( ) 1 necessita de supervisão (observação) quando vira; o queixo movese mais do que a metade da distância do ombro

( ) 0 necessita de ajuda para evitar perder o equilíbrio ou cair; movimento do queixo é menor do que a metade da distância do ombro 


\section{Pegar objeto do chão a partir de uma posição em pé}

INSTRUCÕES: Pede-se para que a criança pegue um apagador de lousa colocado aproximadamente no comprimento dos seus pés, na frente do seu pé dominante. Em crianças em que a dominância não é clara, pergunte para ela qual mão ela quer usar e coloque o objeto à frente do pé correspondente.

EQUIPAMENTO: Um apagador de lousa, uma fita adesiva ou moldes dos pés.

( ) 4 capaz de pegar o pagador de forma segura e facilmente

( ) 3 capaz de pegar o pagador, mas necessita de supervisão (observação)

( ) 2incapaz de pegar 0 apagador, mas alcança a distância de 2 a 5 centímetros do apagador e mantém o equilíbrio de forma independente

( ) 1 incapaz de pegar o pagador; necessita de supervisão (observação) enquanto está tentando

( ) 0 incapaz de tentar, necessita de ajuda para evitar a perda do equilíbrio ou a queda

\section{Colocar o pé alternadamente no apoio enquanto permanece} em pé sem apoio

INSTRUÇÕES: Pede-se à criança que coloque cada pé alternadamente no apoio para os pés (degrau) e continue até que cada pé tenha tocado 0 apoio quatro vezes.

EQUIPAMENTO: Um degrau/apoio para os pés de 10 centímetros de altura, um cronômetro ou relógio de mão.

( ) 4 capaz de permanecer em pé de forma independente e segura e completa 8 toques no apoio em 20 segundos

( ) 3 capaz de permanecer em pé de forma independente e completa 8 toques no apoio em mais que 20 segundos

( ) 2 capaz de completar 4 toques no apoio sem ajuda; mas necessita supervisão próxima (observação)

( ) 1 capaz de completar 2 toques no apoio; necessita de ajuda mínima

( ) 0 necessita de ajuda para manter equilíbrio ou evitar a queda, incapaz de tentar

\section{Alcançar a frente com o braço estendido permanecendo em pé}

Instrução Geral e Instalação: Uma fita métrica, fixada na horizontal em uma parede com as fitas de velcro, será utilizada como ferramenta de medida. Usa-se uma fita adesiva e/ou moldes dos pés para manter o pé estático no chão. Pede-se à criança que alcance a frente o mais longe possível sem cair e sem pisar além da linha. A articulação metacarpofalangiana da mão da criança será utilizada como ponto de referência anatômica para as medidas. Ajuda poderá ser dada para posicionar inicialmente o braço da criança a 90 graus. Não será dado suporte durante o processo de alcance. Se uma flexão de 90 graus do ombro não for atingida, então este item será omitido.

\section{INSTRUCOCOES: Pede-se que a criança levante o braço desta maneira "Estique seus dedos, feche a mão e tente alcançar a frente o mais longe que você puder sem mover seus pés".}

EQUIPAMENTO: Uma fita métrica ou régua, uma fita adesiva ou moldes dos pés, um pequeno nível.

Pontuação média das três tentativas

( ) 4 capaz de alcançar a frente de forma confiante mais que 25 centímetros

( ) 3 capaz de alcançar a frente mais que 12,5 centímetros com segurança

( ) 2 capaz de alcançar a frente mais que 5 centímetros com segurança

( ) 1 capaz de alcançar a frente, mas necessita de supervisão (observação)

( ) 0 perde 0 equilíbrio enquanto está tentando, necessita de apoio externo

Pontuação Total do Teste

PONTUAÇÃO MÁXIMA = 56 